\title{
INTESTINAL PARASITES IN A QUILOMBOLA COMMUNITY OF THE NORTHERN STATE OF ESPÍRITO SANTO, BRAZIL
}

\author{
Schayra Minine DAMAZIO(1), Marcela de Souza LIMA(1), Aparecida Rios SOARES(1) \& Marco Antônio Andrade de SOUZA(1)
}

\begin{abstract}
SUMMARY
The aim of this study was to determine the occurrence of intestinal parasites in a quilombola community from the northern Espírito Santo, Brazil. Descendants of slaves who arrived in Brazil in the sixteenth century, this population settled in the municipality of São Mateus in 1858. Fresh fecal samples from 82 individuals who agreed to participate in the study were collected between August 2009 and July 2010, and immediately sent to the Clinical Laboratory of the Centro Universitário Norte do Espírito Santo of the Universidade Federal do Espírito Santo for analysis. Out of all the participants, 36 (43.9\%) were male and 46 (56.1\%) were female, whose ages ranged from six to 85 years. The study of the occurrence of intestinal parasites indicated that 35 individuals $(42.7 \%)$ were infected with at least one intestinal parasite. Among helminths, the most frequent were hookworms, with a rate of $14.6 \%$. With regard to protozoa, Entamoeba coli, Entamoeba histolyticalEntamoeba dispar and Endolimax nana stood out, with frequencies of $23.2 \%, 8.5 \%$ and $4.9 \%$, respectively. The occurrence of biparasitism was observed in 13 of the 82 subjects, accounting for $15.8 \%$, and no cases of multiple parasitic infections were observed. It was concluded that the reduction of cases of intestinal diseases due to parasites will only be achieved with the improvement of basic sanitation and quality of life of quilombola populations.
\end{abstract}

KEYWORDS: Enteroparasites; Slaves; São Mateus; Health Education; Quilombola.

\section{INTRODUCTION}

Intestinal enteroparasites are considered a serious public health problem, especially in poor and developing countries, where these rates reach an occurrence of up to $90 \%{ }^{23}$. According to data from the Centers for Disease Control and Prevention, it is estimated that approximately 200 million individuals worldwide have Giardia lamblia, 50 million have Entamoeba histolytica/E. dispar, one billion have Ascaris lumbricoides and a slightly smaller number have Trichuris trichiura and hookworms ${ }^{9}$.

Historically, human contamination by parasites dates back thousands of years. Studies of archaeological material have shown the presence of parasites in Africa, Europe, Asia, Oceania and the Americas. Specifically in the Americas, findings in desiccated or mineralized feces and other organic materials identified the presence of hookworms, A. lumbricoides, Hymenolepis nana, T. trichiura, Enterobius vermicularis, Entamoeba spp., G. lamblia and possibly Entamoeba coli ${ }^{16}$.

Last but not least, the African slave trade to Brazil should also be mentioned since it probably contributed to the entry and spread of some parasitic diseases on the continent ${ }^{20}$.

In São Mateus, the slave trade lasted until the year 1856, where they were sold and sent to the various farms. History records the resistance to the slavery system with numerous escapes and the consolidation of quilombola communities in northern São Mateus, probably generating new outbreaks of parasitic diseases in the region. The persecution of quilombola populations was one of the hallmarks of the entire colonial system up until the XX and XXI centuries, with the expulsion of their territories by agribusiness in the 1960s and the elimination of natural resources necessary for the production and reproduction of their culture ${ }^{26}$.

In Brazil, epidemiologic studies indicate that significant portions of the populations analyzed were positive for some parasites, either helminth or protozoa $8,14,25,27,35$.

From a parasitological point of view, people from lower social classes living in places with poor hygiene and unsanitary conditions present a favorable environment for intestinal parasites to develop ${ }^{24,32}$. In this context, quality of life, housing, sanitation and hygiene habits are largely determinant in the process of the development and transmission of intestinal parasite diseases ${ }^{2,23,28}$.

In fact, and according to UNICEF (The United Nations Children's Fund), children under five years of age reflect the level of contamination of a region and therefore the social conditions of their community, 


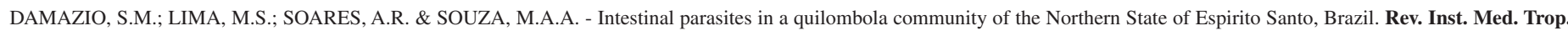
Sao Paulo, 55(3): 179-83, 2013.

since they are individuals with little capacity for locomotion and higher vulnerability ${ }^{29,36}$. At this stage of life, children have habits such as playing on the floor, putting their dirty hands into their mouths, eating with unwashed hands and having contact with pets that may carry parasite eggs in their hair, making them important sources of parasite infection ${ }^{12,13}$.

Caused by numerous different infectious organisms whose transmission mechanisms may or may not involve the presence of intermediate hosts, some of these parasitic diseases can be extremely lethal when they develop into a critical condition for the individual, even those which are considered simple and are easily treated. Nevertheless, the absence of treatment, erroneous treatment and factors inherent to the individual may result in chronic infections that cause severe morbidities ${ }^{11}$.

Despite all government efforts, a discrepancy between the success achieved in developed countries and that which is found in poorer ones can be observed. The lack of planning and investment by governments in therapeutic, preventive and palliative measurements, the lack of educational projects with population participation, and the high financial cost attributed to technical measures are factors that hinder and delay the process of implementing control actions ${ }^{23}$.

In this context, it is important to highlight the difficulties faced by quilombola communities scattered throughout the Brazilian territory, especially in northern Espírito Santo, whose survival becomes a challenge every day. Isolated by large eucalyptus forests and sugar cane crops, many individuals lose their cultural characteristics and young people abandon their origins in search of employment opportunities in major centers, eventually becoming swallowed up by the urban lifestyle'.

In addition, this population has systematically suffered from infection by intestinal parasites, given the precarious sanitation, housing and water treatment conditions of the communities where they live $e^{2,6}$.

Taking into account the data of abandonment of quilombola populations in Brazil, the present study aimed to investigate the occurrence of intestinal parasites in slave descendants in São Mateus, northern Espírito Santo.

\section{MATERIAL AND METHODS}

Description of the study area: The city of São Mateus is located in the northern region of Espírito Santo at coordinates 3951'41' longitude and $18^{\circ} 43^{\prime} 15^{\prime}$ ' latitude. It has an area of $2,343 \mathrm{~km}^{2}$ and a population of 109,028 inhabitants, 84,541 living in the urban area and 24,487 in the rural area ${ }^{19}$. It is the second oldest city and the eighth most populous in the state, founded on September $21^{\text {st }} 1544$ and only gaining municipal autonomy in 1764 . Originally it was called Povoado do Cricaré, but it was renamed São Mateus in the year 1566 by the priest José de Anchieta. It is considered the city with the largest black population in the state, especially quilombola communities of Sapê do Norte, considering that until the second half of the nineteenth century the port of São Mateus was one of the main points of entry for slaves in Brazil. It is noteworthy that the last clandestine shipment of slaves on the Brazilian coast occurred in the mouth of the São Mateus River in 1856.

African slaves who lived in the city were brought from Angola and Guinea, from Bantu, Benguela, Cabidela peoples, to be used as a workforce on plantations, mainly for the production of manioc flour ${ }^{7,26,34}$.

Currently, the region called Sapê do Norte, comprising over thirty quilombola communities, is committed to resuming the territories they traditionally occupied and continuing the process of emancipation. The Community of Santa Maria district, the study site, is located about 30 $\mathrm{km}$ from the city hall in the city of São Mateus, access to which is by dirt roads. It is noteworthy that even today their homes are made with mud and straw, plastered with mud and painted with lime. Most of the residents, represented by 80 families, do not have running water or a sewage system. Some homes have septic tanks. They survive on small crops in small farms measuring from two to ten hectares in the immediate surroundings of their backyards and communities ${ }^{7}$. With extensive eucalyptus and sugar cane plantations deployed by large cellulose and ethanol production companies in the region in the 1960 s, their community has become increasingly isolated ${ }^{1}$.

Ethics Research Committee: The study was initiated after approval by the Ethics Research Committee of the Centro Universitário Norte do Espírito Santo, of the Universidade Federal do Espírito Santo (No. 002/2009) and after the free and informed consent term was signed by parents or legal guardians of individuals who participated in the study. This project received funding resources (Process No. 44795653/09) from the Fundação de Amparo à Pesquisa do Espírito Santo (FAPES) and the Conselho Nacional de Desenvolvimento Científico e Tecnológico (CNPq).

Collection of biological data: Between August 2009 and July 2010, fresh fecal samples were collected from the population of Santa Maria quilombola community, São Mateus, Espírito Santo.

Prior to sample collection, lectures were given to the study population in order to clarify the research objectives and provide guidance on how to collect and store samples. During the occasion, participants signed the informed consent form.

Once collected, the samples were sent and processed on the same day of receipt at the Clinical Laboratory of the Centro Universitário Norte do Espírito Santo of the Universidade Federal do Espírito Santo, by the method of spontaneous sedimentation ${ }^{18}$, and the sediment was examined in triplicate after staining with Lugol.

Parasitological examinations were performed on 82 subjects, 36 (43.9\%) male and $46(56.1 \%)$ female, whose ages ranged from six to 85 years. Individuals younger than 40 years accounted for $65.8 \%$ of the total participants and the percentage of children and adolescents of school age was $46.3 \%$. The fecal samples provided by all participants were sufficient to carry out the study.

The results of the parasitological examinations were delivered to each of the participants, and when intestinal parasites were found, participants were given information, through lectures on education and health, and referred to local health units for treatment.

\section{RESULTS}

The study of the occurrence of intestinal parasites indicated that 35 individuals $(42.7 \%)$ were infected with at least one intestinal parasite. Among helminths, the most prevalent were hookworms, with a rate 
of $14.6 \%$. Regarding protozoa, E. coli, E. histolytica/E. dispar and Endolimax nana stood out with frequencies of $23.2 \%, 8.5 \%$ and $4.9 \%$, respectively. With respect to Strongyloides stercoralis, only one individual had become infected. This result may be underestimated due to the use of techniques which are not suitable for the diagnosis of this parasite.

Of the 82 samples, 15 were positive for helminths, 33 for protozoa and six contained parasites from both groups. The frequency of parasites is described in Table 1.

\section{Table 1}

Frequency of intestinal parasites in the quilombola population of São Mateus, Espírito Santo, Brazil, 2010

\begin{tabular}{lcc}
\hline Species & $\mathrm{N}$ & Frequency $(\%)$ \\
\hline Hookworms & 12 & 14.6 \\
Ascaris lumbricoides & 1 & 1.2 \\
Strongyloides stercoralis & 1 & 1.2 \\
Trichuris trichiura & 1 & 1.2 \\
Endolimax nana & 4 & 4.9 \\
Entamoeba coli & 19 & 23.2 \\
Entamoeba histolytica/E. dispar & 7 & 8.5 \\
Giardia lamblia & 2 & 2.4 \\
\hline
\end{tabular}

The occurrence of biparasitism was observed in 13 of 82 subjects, accounting for $15.8 \%$ (Table 2). There were no cases of multiple parasitic infections.

Table 2

Association of intestinal parasites in the quilombola population of São Mateus, Espírito Santo, Brazil, 2010

\begin{tabular}{lc}
\hline Biparasitism & Cases \\
\hline Ascaris lumbricoides and Entamoeba coli & 1 \\
Hookworms and Entamoeba coli & 2 \\
Entamoeba coli and Entamoeba histolytica/E. dispar & 4 \\
Hookworms and Entamoeba histolytica/E. dispar & 2 \\
Endolimax nana and Entamoeba coli & 3 \\
Hookworms and Trichuris trichiura & 1 \\
\hline Total & $13(15.8 \%)$ \\
\hline
\end{tabular}

When analyzing the positivity among age groups, it was observed that the highest frequency of infection $(20.7 \%)$ corresponded to individuals over 21 years of age (Table 3 ).

\section{DISCUSSION}

The contribution that studies of the occurrence of intestinal parasites can offer to quilombola descendants is immense, especially when considering that they represent a class which has been historically marginalized by society. They were officially recognized by the Brazilian government in 1988, with the assertion of their territorial rights through
Table 3

Frequency of intestinal parasites by age group in the quilombola population of São Mateus, Espírito Santo, Brazil, 2010

\begin{tabular}{lcc}
\hline Age group (years) & $\mathrm{N}$ & Frequency $(\%)$ \\
\hline 6 to 14 years & 15 & 18.3 \\
14 to 21 years & 3 & 3.7 \\
$>$ 21 years & 17 & 20.7 \\
\hline Total & 35 & 42.7 \\
\hline
\end{tabular}

Article 68 of the Temporary Constitutional Provisions Act ${ }^{5}$, in which there are few reports of the occurrence of parasitic infections in this population.

Accordingly, the results of this study indicate that the occurrence of intestinal parasites is $42.7 \%$, which is cause for concern considering the population affected and the parasitic species found. Among them, $E$. histolytica/E. dispar stand out, which cause amebiasis, a disease that has led to the death of 40 to 100 thousand individuals annually worldwide and is considered the second leading cause of death among parasitic diseases. Its most frequent clinical manifestation is acute amebic colitis ${ }^{33}$, but it may also take on invasive intestinal and extraintestinal forms. The findings of E. histolytica/E. dispar point to the risk of infection by this parasite, however one must consider the need for laboratory molecular diagnostics for real differentiation between these species.

Moreover, the high infection rate by $E$. coli, although unable to produce pathogenic forms, is an important indicator of contamination by other protozoan parasites, especially when considering an easy transmission protozoan ${ }^{22,30}$.

Another enteroparasite found was G. lamblia. When contaminating an individual, it leads to acute or persistent diarrhea, with evidence of malabsorption and weight loss ${ }^{17}$. It is noteworthy that among protozoa, this is the one whose cyst remains viable for longer in the external environment and resists the usual chlorination of water ${ }^{2}$, thus playing an important role in the dynamics of disease transmission.

Among the helminth species found, the presence of hookworms geohelminths parasites was verified, which can cause infection in the small intestine of humans with symptoms of severe anemia and hypoproteinemia. The eggs of these parasites require favorable environmental conditions for good oxygenation, humidity and temperature for embryogeny ${ }^{21,31}$. The positivity for these parasites shows that the quilombola locality has favorable environmental conditions for the development of these parasites, contributing to the maintenance and dissemination of ancylostomiasis.

In fact, the diversity of parasites found in the quilombola population of São Mateus and their frequencies, E. coli (23.2\%), E. histolytica/E. dispar (8.5\%), E. nana (4.9\%); G. lamblia (2.4\%) and hookworms $(14.6 \%)$ suggest that the geographical distribution of parasites may depend on several factors such as poor hygiene conditions, lack of health education and favorable environmental conditions for the development of phases of parasite cycles, as observed by the authors studying the occurrence of intestinal parasites in quilombola community in the municipality of Bias Fortes, State of Minas Gerais and in the indigenous 
DAMAZIO, S.M.; LIMA, M.S.; SOARES, A.R. \& SOUZA, M.A.A. - Intestinal parasites in a quilombola community of the Northern State of Espirito Santo, Brazil. Rev. Inst. Med. Trop. Sao Paulo, 55(3): 179-83, 2013.

community Mbyá-Guarani of Porto Alegre, state of Rio Grande do sul ${ }^{3,4}$.

Regarding education, many difficulties were found with respect to the existence of schools in the community, especially when considering the instability and neglect of quilombola school education by the government. It is noteworthy that education is a social foundation fundamental to cultural development and therefore the precept of health.

Regarding the poor hygiene conditions of the population, although efforts have been made by government health agencies to reduce the rates and impacts of diseases caused by intestinal parasites, this is one of the factors that most contribute to the dissemination of parasitic diseases, especially in communities of African descent, minority groups and at the margins of society ${ }^{10}$.

On the other hand, some studies have shown a decline in the occurrence of parasites, which is closely related to improvements of basic sanitation conditions and therefore improvements in quality of life. One of these studies showed the need to establish a health policy focused not only on the diagnosis and specific treatment of infected individuals but also on eliminating sources of infection, while another showed significant reductions in the occurrence of parasites in general (from $30.9 \%$ to $10.7 \%$ ), helminthiasis (from $22.3 \%$ to $4.8 \%$ ), giardiasis ( $14.5 \%$ to $5.5 \%$ ), and multiple intestinal parasites (13.1\% to $0.5 \%$ ) in children from the city of São Paulo (1984-1996), which is attributed to increases in family income, maternal education, housing, basic sanitation and access to health services ${ }^{14,15}$.

Thus, it is expected that simple health education actions focused on the quilombola population of São Mateus, respect for their culture, their artistic manifestations and social rights, can reflect on a better quality of life for the entire community, especially when a reduction of infection by intestinal parasites is achieved.

\section{RESUMO}

\section{Parasitos intestinais em comunidade quilombola do Norte do Espírito Santo, Brasil}

O objetivo do presente estudo foi determinar a ocorrência de parasitos intestinais em população quilombola do Norte do Espírito Santo. Descendentes de escravos que chegaram ao Brasil a partir do século XVI, essa população estabeleceu-se no município de São Mateus no ano de 1858. Entre agosto de 2009 e julho de 2010, amostras fecais de 82 indivíduos que aceitaram participar do trabalho foram coletadas, a fresco, e, imediatamente, encaminhadas ao Laboratório de Análises Clínicas do Centro Universitário Norte do Espírito Santo da Universidade Federal do Espírito Santo para análise. Do total de participantes, $36(43,9 \%)$ eram do sexo masculino e $46(56,1 \%)$ do sexo feminino, cujas idades variaram de seis a 85 anos. $\mathrm{O}$ estudo de ocorrência das enteroparasitoses indicou que 35 indivíduos $(42,7 \%)$ apresentaram-se infectados por pelo menos um parasito intestinal. Entre os helmintos, os mais frequentes foram os ancilostomídeos com taxa de 14,6\%. Com relação aos protozoários, destacaram-se Entamoeba coli, Entamoeba histolytica/Entamoeba dispar e Endolimax nana com 23,2\%, $8,5 \%$ e $4,9 \%$, de frequência, respectivamente. A ocorrência de biparasitismo foi verificada em 13 dos 82 participantes do estudo, o que representa $15,8 \%$ e não foram observados casos de poliparasitismo. Conclui-se que a redução dos índices de parasitoses intestinais somente será alcançada com a melhoria das condições de saneamento básico e da qualidade de vida da população quilombola.

\section{ACKNOWLEDGMENTS}

To Angélica Tedesco from the Regional Board of Education of São Mateus for her effort in the selection process of students involved in the project.

To students from the "Córrego de Santa Maria" Elementary and High School, Marciana Dias de Souza, Nilvana do Nascimento Souza, Sabrina Bernadino Teodoro, Edvan dos Santos Oliveira and Willian Feliciano Jorge for all the support in making collections and preparing material for analysis.

\section{REFERENCES}

1. Abreu ELB. Identidade cultural: comunidades quilombolas do extremo sul da Bahia em questão. Rev África Africanidades. 2010;8:1-12.

2. Andrade EC, Leite ICG, Rodrigues VO, Cesca, MG. Parasitoses intestinais: uma revisão sobre seus aspectos sociais, epidemiológicos, clínicos e terapêuticos. Rev APS. 2010;13:231-40.

3. Andrade EC, Leite ICG, Vieira MT, Abramo C, Tibiriçá SHC, Silva PL. Prevalência de parasitoses intestinais em comunidade quilombola no município de Bias Fortes, Estado de Minas Gerais, Brasil, 2008. Epidemiol Serv Saude. 2011;20:337-44.

4. Brandelli CL, De Carli GA, Macedo AJ, Tasca T. Intestinal parasitism and socioenvironmental factors among Mbyá-Guarani indians, Porto Alegre, Rio Grande do Sul, Brazil. Rev Inst Med Trop Sao Paulo. 2012;54:119-22.

5. Brasil. Constituição. Ato das Disposições Constitucionais Transitórias da Constituição. Brasília: CRFB; 1988.

6. Cabral-Miranda G, Dattoli VCC, Dias-Lima A. Enteroparasitos e condições socioeconômicas e sanitárias em uma comunidade quilombola do semiárido baiano. Rev Patol Trop. 2010;39:48-55.

7. Calazans M. Agricultura, identidade e território no Sapê do Norte quilombola. Agriculturas. 2010;7:7-12.

8. Campos R, Briques W. Levantamento multicêntrico de parasitoses intestinais no Brasil. Os resultados finais. São Paulo: Rhodia; 1988. Apud: Carvalho OS. Prevalência de helmintos intestinais em três mesorregiões do Estado de Minas Gerais. Rev Soc Bras Med Trop. 2002;35:597-600.

9. Centers for Disease Control and Prevention. Epidemiology and risk factors. Atlanta: CDC; 2010.

10. Chor D, Lima CR. Aspectos epidemiológicos das desigualdades raciais em saúde no Brasil. Cad Saude Publ. 2005;21:1586-94.

11. Colley DG. Parasitic diseases: opportunities and challenges in the $21^{\text {st }}$ century. Mem Inst Oswaldo Cruz. 2000;95:79-87.

12. Costa-Macedo LM, Rey L. Frequency and precocity of human intestinal parasitism in a group of infants from Rio de Janeiro, Brazil. Rev Inst Med Trop São Paulo. 1997;39:305-6.

13. Costa-Macedo LM, Costa MC, Almeida LM. Parasitismo por Ascaris lumbricoides em crianças menores de dois anos: estudo populacional em comunidade do Estado do Rio de Janeiro. Cad Saude Publica. 1999;15:173-8.

14. Ferreira MU, Ferreira CS, Monteiro CA. Tendência secular das parasitoses intestinais na infância na cidade de São Paulo (1984-1996). Rev Saude Publica. 2000;34(Supl 6):73-82. 
15. Fontes G, Oliveira KK, Oliveira AK, Rocha EM. Influência do tratamento específico na prevalência de enteroparasitoses e esquistossomose mansônica em escolares do município de Barra de Santo Antônio, AL. Rev Soc Bras Med Trop. 2003;36:625-8.

16. Gonçalves ML, Araújo A, Ferreira LF. Human intestinal parasites in the past: new findings and a review. Mem Inst Oswaldo Cruz. 2003;98(Supl 1):103-18.

17. Guimarães S, Sogayar MITL. Giardia. In: Neves DP, Melo AL, Linardi PM, Vitor RWA, editores. Parasitologia humana. São Paulo: Atheneu; 2005. p. 121-6.

18. Hoffmann WA, Pons JA, Janer JL. The sedimentation concentration method in Schistosoma mansoni. J Public Health Trop Med. 1934;9:283-98.

19. Instituto Brasileiro de Geografia e Estatística. IBGE. Brasil. Censo 2010: primeiros resultados. Brasília: IBGE; 2010.

20. Kodama K. Os debates pelo fim do tráfico no periódico O Philantropo (1849-1852) e a formação do povo: doenças, raça e escravidão. Rev Bras Hist. 2008;28:407-30.

21. Leite ACR. Ancylostomidae. In: Neves DP, Melo AL, Linardi PM, Vitor RWA, editores. Parasitologia humana. São Paulo: Atheneu; 2005. p. 261-9.

22. Lopes LM, Santos ES, Savegnago TL, Salvador FA, Ribeiro-Barbosa ER. Ocorrência de parasitas comensais intestinais em crianças da comunidade da Vila Inglesa, em São Paulo, SP, Brasil. Rev Inst Adolfo Lutz. 2010:69:252-4.

23. Ludwig KM, Frei F, Alvares Filho F, Ribeiro-Paes JT. Correlação entre condições de saneamento básico e parasitoses intestinais na população de Assis, Estado de São Paulo. Rev Soc Bras Med Trop. 1999;32:547-55.

24. Machado RC, Marcari EL, Cristante SFV, Carareto CMA. Giardíase e helmintíases em crianças de creches e escolas de $1^{\circ}$ e $2^{\circ}$ graus (públicas e privadas) da cidade de Mirassol (SP, Brasil). Rev Soc Bras Med Trop. 1999;32:697-704.

25. Montanholi FAF, Merlo F, Cavazzana Jr M, Gonçalves PA, Gonçalves RVV. Avaliação da infestação por agentes infecciosos e parasitários em dinheiro na cidade de Catanduva - SP. Rev Estud Univ. 2008;34:47-54.

26. Nardoto E, Lima H. História de São Mateus. 2. ed. São Mateus: EDAL; 2001. 463 p.
27. Oliveira GG, Teti CMF, Lima ICO, Fernandez BO, Silva AM, Santos LV. Prevalence of intestinal parasitoses in families of landless workers movement. J Nurs UFPE. 2012;6:2490-6.

28. Pedroso RS, Siqueira RV. Pesquisa de cistos de protozoários, larvas e ovos de helmintos em chupetas. J Pediatr (Rio J). 1997;73:21-5.

29. Quadros RM, Marques S, Arruda AA, Delfes PS, Medeiros IA. Parasitoses intestinais em centros de educação infantil municipal de Lages, SC, Brasil. Rev Soc Bras Med Trop. 2004;37:422-3.

30. Reis RM, Carneiro LC. Indicador higiênico-parasitário em manipuladores de alimentos em Morrinhos, GO. Rev Estudos Biol. 2007;29:313-7.

31. Rey L. Um século de experiência no controle da ancilostomíase. Rev Soc Bras Med Trop. 2001;34:61-7.

32. Rocha RS, Silva JG, Peixoto SV, Caldeira RL, Firmo JOA, Carvalho OS, et al. Avaliação da esquistossomose e de outras parasitoses intestinais, em escolares do município de Bambuí, Minas Gerais, Brasil. Rev Soc Bras Med Trop. 2000;33:431-6.

33. Santos FLN, Soares NM. Mecanismos fisiopatogênicos e diagnóstico laboratorial da infecção causada pela Entamoeba histolytica. J Bras Patol Med Lab. 2008;44:249-61.

34. São Mateus. Prefeitura. História de São Mateus. São Mateus: Prefeitura Municipal de São Mateus; 2011.

35. Silva MG, Teixeira DJ, Gontijo EEL. Prevalência de parasitas intestinais em alunos de 5 a 12 anos da rede pública do município de Gurupi, Tocantins, Brasil. Rev Eletrôn Farm. 2012;9:13-24.

36. The United Nations Children's Fund. The state of the world's children. New York: UNICEF; 1995.

Received: 25 September 2012

Accepted: 3 December 2012 


\section{Revista do Instituto de Medicina Tropical de São Paulo on line.}

Publications from 1987 to the present data are now available on:

http://www.scielo.br/rimtsp

PAST ISSUES 1959-1989 (PDF)

www.imt.usp.br/portal/

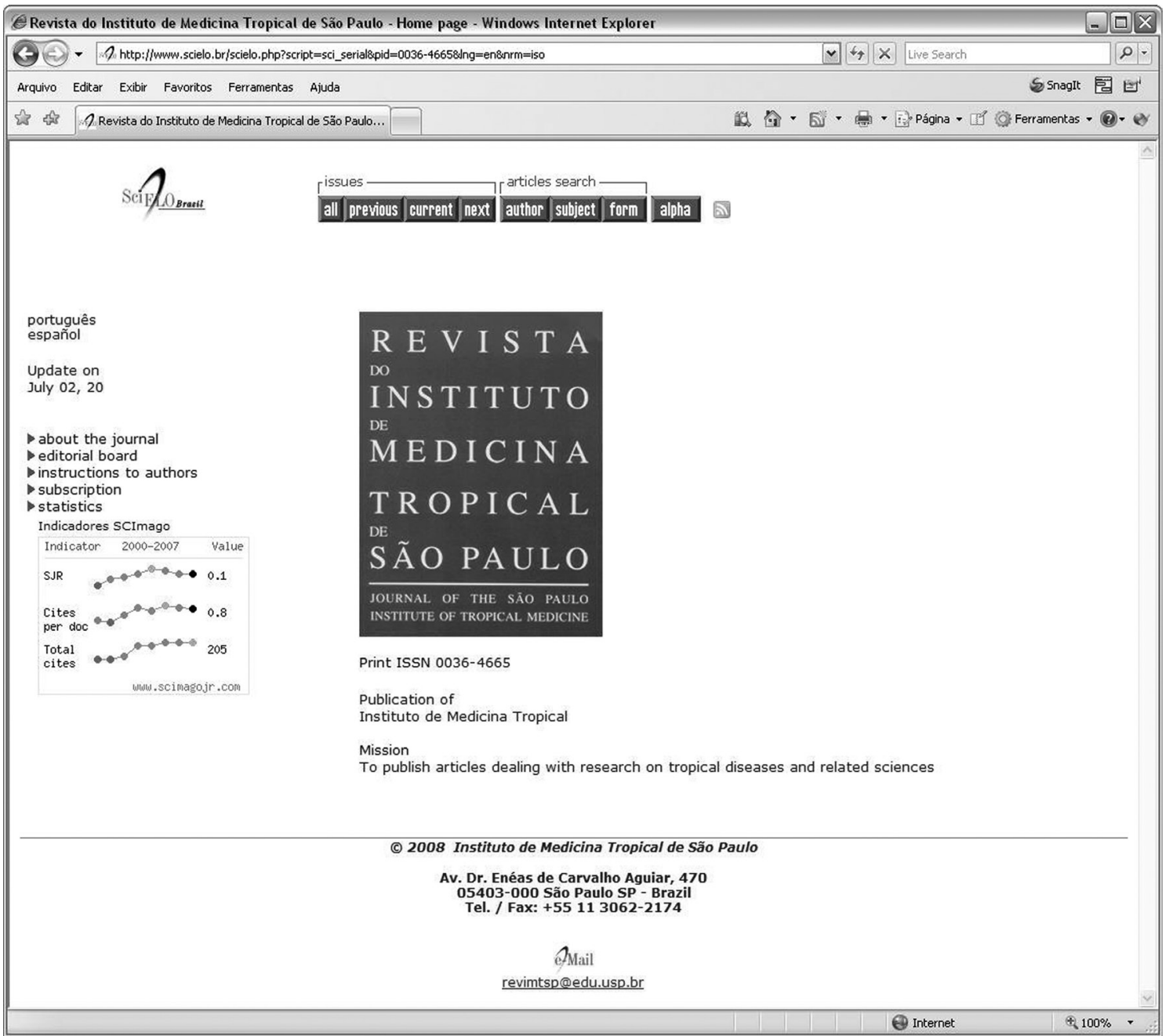

SciELO - The Scientific Electronic Library OnLine - SciELO is an electronic virtual covering a selected collection of Brazilian scientific journals.

The library is an integral part of a project being developed by FAPESP - Fundação de Amparo à Pesquisa do Estado de São Paulo, in partnership with BIREME - the Latin American and Caribbean Center on Health Sciences Information.

SciELO interface provides access to its serials collection via an alphabetic list of titles or a subject index or a search by word of serial titles, publisher names, city of publication and subject.

The interface also provides access to the full text of articles via author index or subject index or a search form on article elements such as author names, words from title, subject and words from full text.

FAPESP/BIREME Project on Scientific Electronic Publications Latin American and Caribbean Center on Health Sciences Information

Rua Botucatu 862 - 04023-901 São Paulo, SP - Brazil

Tel. (011) 5576-9863

scielo@bireme.br 